\section{Atitudes linguísticas em torno da língua de imigração e a sua (não) transmissão}

Linguistic attitudes around the immigration language and its (non) transmission

Franciele Maria MARTINY (UNILA) franciele.martiny@unila.edu.br

\title{
00000000000
}

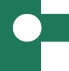

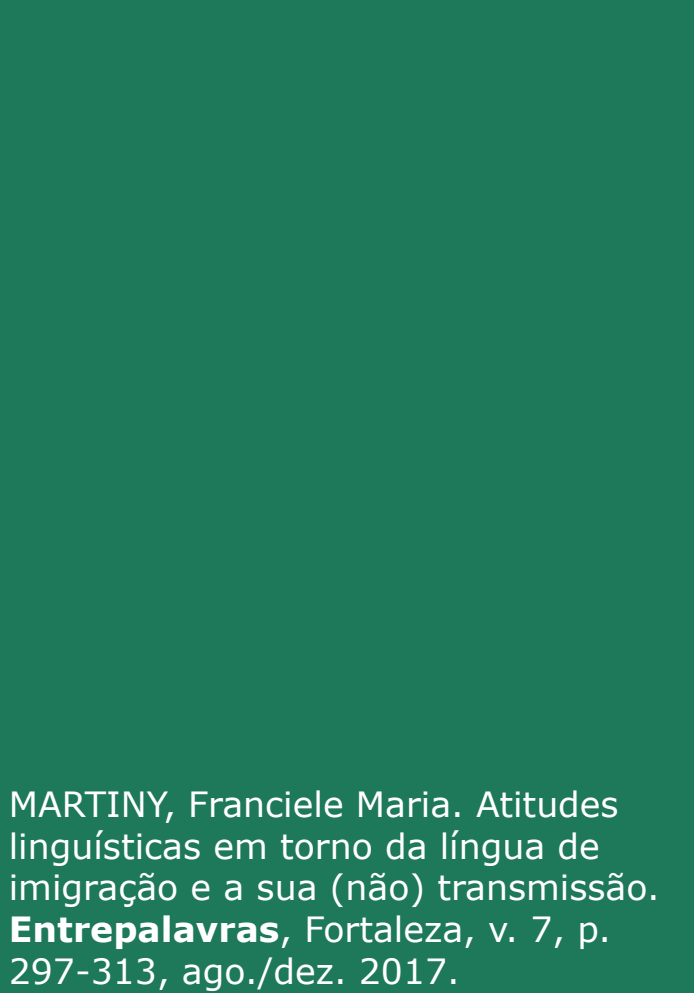

Resumo: Este artigo apresenta reflexões sobre as atitudes linguísticas de falantes bilíngues, de uma cidade localizada no Oeste do Paraná, em dados levantados durante a Tese de Doutoramento (MARTINY, 2015) sobre políticas linguísticas em torno da língua alemã. Na referida pesquisa, de viés qualitativo, constatou-se, por meio de entrevistas, que um dos motivos para a não manutenção da língua de imigração na comunidade está diretamente relacionado ao contato com a língua de prestígio, o português, e o estigma que grupos apresentam com relação à língua minoritária, o alemão, o que culmina na decisão dos pais e avós de não a falarem mais e, ao mesmo tempo, a não transmissão dessa aos filhos. Nesse sentido, a partir do aporte teórico da sociolinguística, verifica-se a complexa relação entre sociedade e língua, refletida nas atitudes dos falantes e na diminuição da interação em alemão na localidade.

Palavras-chave: Atitudes linguísticas. Língua de imigração. Não transmissão da língua alemã. 
v. 7 (2)

297-313

ago/dez 2017

Abstract: This article presents reflections about linguistic attitudes of bilingual speakers, from a city located in the west of Paraná, in data collected during tehe doctorate thesis about linguistic politics in relation to German language. In this study, which is qualitative, it was found, by means $\mathrm{f}$ interviews, that one of the reasons for not maintaining the immigrant language in the community is directly related to the contact with the language of prestige, Portuguese, and the stigma that groups present in relation to the minority language, German, which culminates in the parents' decision not to speak it anymore and, at the same time, not to transmit it to their children. Therefore, based on the theoretical contribution of sociolinguistics, there is a complex relationship between society and language, reflected in the attitudes of the speakers and in the decrease of the interaction in German in the locality.

Keywords: Linguistic attitudes. Imigrant language. Not transmission of the German language.

\section{Considerações iniciais}

Durante a realização da Tese de Doutorado (MARTINY, 2015), debruçou-se sobre questões que envolvem as políticas linguísticas em torno da língua alemã, sendo essa a língua de imigração da comunidade pesquisada, localizada no Oeste do Paraná. No levantamento de dados para a pesquisa, esbarrou-se no fato de que muitos dos entrevistados, mesmo sendo conhecedores da referida língua, não estão mais interagindo verbalmente e, tampouco, ensinaram-na aos seus filhos. Essa situação chamou, em especial, a atenção, nas entrevistas, pois a mesma situação foi vivenciada pela pesquisadora em seu contexto familiar, e, além disso, dialoga com o que está sendo observado constantemente na comunidade ao longo dos últimos anos.

Diante desse contexto, mesmo não sendo o objetivo principal da pesquisa naquele momento, optou-se em questionar o(s) motivo(s) dessa não transmissão, ou seja, a justificativa do não ensino da língua alemã de maneira informal na família, uma vez que esse cenário tem estreita relação com as atitudes dos pais perante a língua. Decisão que, por conseguinte, leva a outras reflexões que culminam na pouca procura pelo ensino formal e pela não manutenção da língua na localidade, principalmente nas gerações mais novas. Uma vez que as atitudes são também responsáveis pela eleição de uma língua em detrimento de outra e do ensino-aprendizagem de línguas na comunidade (MORENO FERNANDÉZ, 1998).

Calvet (2002) ressalta não ser somente os pais os responsáveis pela não transmissão de uma dada língua, ou seja, pela sua manutenção, mas todo o contexto histórico-social em que o falante está envolvido, o que auxilia ou inibe o bilinguismo em diferentes graus. Por isso, 
retoma-se o referido teórico (2002), que afirma que é preciso também considerar que atitudes linguísticas têm uma ligação com atitudes culturais.

Nas palavras de Lambert e Lambert "[...] uma atitude é uma maneira organizada e coerente de pensar, sentir e reagir em relação a pessoas, grupos, questões sociais ou, mais genericamente, a qualquer acontecimento ocorrido e, nosso meio circundante" (1966, p. 77). Nota-se, por este viés, a preocupação com os aspectos social, ideológico e cultural da linguagem, tornando mais complexos os estudos da diversidade linguística. Nesse sentido, é preciso levar em consideração a relação entre os grupos étnicos com seus traços identitários, o que desencadeia certos comportamentos linguísticos.

É a partir desse direcionamento que serão feitas as reflexões a seguir neste artigo, trazendo informações sobre o contexto sóciohistórico-cultural e linguístico da localidade pesquisada, alternando-se com os estudos da Sociolinguística, como uma área baseada na relação existente entre a "estrutura linguística e os aspectos sociais e culturais da produção linguística" (CEZARIO; VOTRE, 2009, p. 141). Elege-se esse embasamento teórico, uma vez que os estudos sociolinguísticos atrelam a questão linguística à questão social, visando a percepção dos dados linguísticos presentes na comunidade, que são capazes de estabelecer o caráter heterogêneo da língua, ressaltando os aspectos da variação linguística e as complexas relações de poder.

A formação cultural germânica do município e as línguas em conflito

Como já citado, o município focalizado neste estudo está localizado no Oeste do Paraná, região considerada sociolinguisticamente complexa pela presença de várias etnias e línguas em contato. No caso do município pesquisado, a maior parte da população é descendente de imigrantes alemães, sendo assim, por algumas décadas, houve muitos falantes bilíngues português/alemão, na localidade, principalmente pessoas da faixa etária de 45 a 85 anos, que mantinham a língua na interação comunicativa em contexto familiar, em contato também com vizinhos ou em grupos mais próximos de suas relações sociais.

Esse contexto retoma o crescimento do fluxo imigratório, na citada região, que ocorreu na segunda metade do século XIX com a participação de várias etnias/nacionalidades, destacando-se portugueses, italianos, espanhóis e alemães. 
v. $7(2)$ 297-313 ago/dez 2017

No caso dos alemães, vários se tornaram proprietários de terras, com a tendência para a formação de pequenas áreas de terras mais ou menos homogêneas, a fim de manter tradições de sua terra natal. Tais deslocamentos ganharam mais intensidade e abrangência a partir da segunda década do século XX, chegando ao Oeste catarinense e ao Sudoeste e Oeste parananenses.

Um dos estudiosos que enfatizam a forte presença de descendentes alemães no município é Targanski (2007). Segundo seus apontamentos, houve, na época, a dificuldade de aceitação de outros povos na localidade, sendo que cada vez mais os grupos homogêneos se estabeleciam, amparados pela empresa responsável pela colonização, que criava empecilhos para intimidar a migração de outros que não fossem descendentes europeus.

Situação também citada por Saatkamp (1984), quando em seus estudos, mostra que, em 1956, a população da localidade era constituída por 95\% de famílias descendentes de alemães, enquanto os $5 \%$ restantes pertenciam a famílias italianas ou luso-brasileiras. Até 1990, a situação permaneceu praticamente igual, totalizando $85 \%$ de descendentes alemães no município, de acordo com a pesquisa desenvolvida por von Borstel (1992).

Nesse sentido, no aspecto da colonização, depreende-se o incentivo à hegemonia populacional que se formaria, e permitiria a manutenção da língua e cultura germânica, como de fato ocorreu por décadas, principalmente com o incentivo a festas típicas alemãs com pratos típicos e ao incentivo à construção de fachadas de prédios públicos em estilo germânico.

Entretanto, em contato com a língua e cultura nacional, a língua e a cultura desse grupo apresentaram (e continuam apresentando) uma forte hibridização, o que desencadeia, na questão linguística, a variação em ambas as línguas, por meio da criação de palavras com base na própria língua brasileira, ou de palavras adotadas da língua de origem étnica cultural.

Sobre esse contexto, von Borstel (1992, 1999, 2011) menciona, em suas pesquisas, o fenômeno linguístico do code-switching no uso do português e do alemão, formando o "Brasildeutsch" - uma variedade suprarregional da língua composta por enunciados da língua padrão, das variáveis dialetais regionais do falar alemão e do português.

Devido a esses contatos e hibridizações, muitas vezes, verificouse que moradores da localidade julgam não saber falar alemão ou não 
se consideram bilíngues, porque falam graus variados da língua de imigração e/ou por falarem um dialeto que é desprestigiado por parte da própria comunidade ou por visitantes, chamado de Hunsrückisch, que justamente aprenderam no convívio familiar, fazendo a alternância linguística entre português e alemão na conversação. Diante disso, muitos falantes acreditam que não falam o alemão da Alemanha e, portanto, não é a língua alemã.

De semelhante forma, Fritzen (2008) traz relatos em seu estudo, citando dois casos nos quais os falantes possuem receio de que deixem "escapar" traços linguísticos do alemão na sua fala, causando insegurança e vergonha. A autora avalia que

[...] as representações sobre os descendentes de alemães e sua língua, construídas nos discursos hegemônicos, têm afetado os teuto-brasileiros e provocado a "baixa auto-estima linguística" dos falantes de alemão da região. Eles acabam por assimilar o discurso do preconceito lingüístico preconizado pelas representações de língua do grupo majoritário (Grosjean, 1982) ao adotarem atitudes negativas com relação à língua do seu grupo, ao reproduzirem estereótipos, ao verem-se como falantes que corrompem o alemão ("wir sind Deutschverderber" - nós corrompemos o alemão), a ponto de terem de se desculpar pela língua que falam, como fez o vendedor de peixe que semanalmente vem a minha casa: "A senhora desculpa esse nosso alemão caipira" (FRITZEN, 2008, p. 348).

Nesse sentido, o que se percebe é que o bilinguismo, muitas vezes, é e foi "evitado", a começar na própria fase infantil, momento em que as crianças que falavam alemão em casa começaram a frequentar a escola, devido justamente ao preconceito linguístico e cultural presente em comunidades teuto-alemãs, principalmente atrelado ao sotaque germânico, que era considerado "um sotaque colono" pelos demais alunos.

Para ilustrar essa situação, tem-se o seguinte relato

Eu sofri muito lá, não tanto no quarto ano da época, mas do quinto em diante, até o oitavo, porque as colegas aqui da cidade, eu vim estudar na cidade, elas falavam "coraçon" e eu não entendia no começo porque elas falavam isso, o "çon" de repente elas faziam uma piada, né? E no começo eu não tava entendendo que era para mim, né? Daí eu fui começando a me ouvir, eu tinha uma professora que fazia com que eu ouvisse a minha voz, é:: então é coração, né? Por exemplo, "Rondon" e não "Rondão", ou aquela coisa toda, o erre também, não é só 
v. 7 (2) 297-313 ago/dez 2017

alemão, mas italiano também. [...]. Mas eu sofri um tempão, tinha uma época que eu evitava até de falar, porque eu pensava que estava falando errado (Trecho entrevista Tese MARTINY, 2015, p.270).

Verifica-se, na fala desse entrevistado, um fenômeno linguístico comum aos adstratos alemão e italiano, referente à monotongação do ditongo decrescente nasal tônico final e vice-versa (on-ão). No entanto, o que fica ressaltado é o estigma linguístico que esse falante sofreu por parte dos colegas de escola devido ao seu falar.

Percebe-se que o estigma linguístico é evidentemente um dos fatores inibidores do falar alemão devido, por exemplo, à variação fonética que o falante transfere ao português.

Outra questão que envolve a inibição do falar alemão foi a sua proibição nas escolas devido à crença de que as crianças somente aprenderiam o português quando deixassem de falar a língua étnica atitude que ainda pode ser notada no discurso e em diversas práticas didático-pedagógicas em escolas dessas comunidades (SCHNEIDER, 302 2007).

A esse respeito, Camacho (2013) menciona que, se a variedade é considerada socialmente estigmatizada em face à norma padrão, preconizada pela escola, instaura-se um conflito entre o conhecimento que o falante tem, das práticas de que participa na comunidade, com os valores que a instituição escolar pretende inculcar.

Portanto, diante desse cenário, muitos pais decidiram não transmitir mais a língua alemã aos seus filhos devido a esse contexto diglóssico, de conflito entre as línguas e as variedades linguísticas.

A respeito disso, retoma-se Fritzen, para quem:

Essa situação dos "deslocados" se torna ainda mais grave e complexa quando constatamos que os grupos descendentes de imigrantes sofrem duplo preconceito. Quando falam alemão, falam um alemão corrompido, que "não é mais alemão", e precisam se desculpar por isso; quando falam português, as marcas do alemão denunciam sua origem social e étnica: "são colonos alemães" (FRITZEN, 2008, p. 349).

Verifica-se, assim, que quanto mais positiva for a relação do falante com a cultura em que uma língua é falada, mais favorável será o uso e a aquisição dessa. O inverso também é verdadeiro, as atitudes culturais negativas tendem a provocar rejeições linguísticas. 
A respeito do assunto, Altenhofen (2013) adverte que

Muitos dos conflitos que ocorrem em sociedades plurilíngues, com presença de línguas minoritárias, derivam do equívoco de delegar todas as responsabilidades do destino das línguas ao Estado (ou à escola como instrumento do Estado) e supor equivocadamente que as ações individuais em relação às línguas não têm qualquer efeito sobre esses conflitos, que se acredita serem resolvidos exclusivamente por ações do poder público (ALTENHOFEN, 2013, p. 104).

Nesse contexto, para compreender os fatores que levam os pais a promover o bilinguismo familiar ou não, faz-se necessário observar o modo como a língua e a cultura são percebidas nesse processo.

É o que se pode relacionar com o cenário da localidade pesquisada, pois, pelos relatos e vivências tidas ao longo deste estudo e da vida, sempre se observou o estigma em torno da fala alemã, principalmente quando havia a variação na língua portuguesa ou mesmo o estereótipo criado pela figura do alemão antigo, antiquado, sem estudo e atrapalhado, contexto que ficará mais claro nas análises a seguir.

As atitudes dos falantes e a não preservação da língua de imigração

A partir das reflexões até este momento, verifica-se que as atitudes dos falantes em torno da língua minoritária, quando são de não prestígio, corroboram a não valorização do ensino e a aparente não ligação estabelecida pela comunidade entre cultura e língua.

Nas palavras de Calvet, "un idioma no sólo desparece porque otro o domina, sino también e quizás sobre todo porque los ciudadanos acetan o deciden abandonarlo no transmitirlo a sus hijos" (CALVET, 2000, s/p). Diante disso, percebe-se o papel fundamental da manutenção de uma língua por meio do ensino dessa no próprio entorno familiar.

Percebeu-se que, no momento em que são indagados sobre o assunto do não ensinamento da língua de imigração aos filhos (muitos deles tendo o alemão como língua materna), houve um desconforto por parte dos entrevistados, alternado com momentos de silêncio, talvez reflexões realmente sobre o que teria acontecido.

Uma das respostas obtidas revela essa situação:

[...] o que aconteceu... o que eu vou responder agora? Vou ter que pensar eu e na minha filha. Quando ela passou de comissária de bordo para voo internacional, eu gastei um 
v. 7 (2)

297-313

ago/dez 2017

monte de dinheiro para ela estudar na Alemanha e depois ela foi para o Canadá, fazer o inglês, mais um meio ano, são coisas que eu enquanto professor de inglês, como professor de alemão, eu deveria ter ensinado. Eu como professor não ensinei para minha filha, se eu como professor de línguas não me preocupei, como vou falar dos outros? Por que eu também não sei (Trecho entrevista Tese MARTINY, 2015, p. 264).

Essa constatação do entrevistado revela que, normalmente, a língua majoritária do país prevalece também no lar, pois não há, muitas vezes, a preocupação dos pais de que seus filhos sejam bilíngues, a importância maior é de que os filhos saibam a língua nacional, que seria a necessária para a maioria das situações comunicativas. Então, a língua de imigração passa a ser menos falada e aprendida. Também mostra a falta de respostas, pois, muitas vezes, os pais nem se atentaram ao fato de quão importante teria sido ensinar uma segunda língua aos filhos.

Considera-se que o ambiente imediato da família (parentes, amigos, colegas de trabalho) é diretamente responsável por influenciar, tanto positiva quanto negativamente, as famílias pela opção de ensinar ou não a seus filhos uma determinada língua.

Nesse sentido, Coelho (2009) faz menção aos lares formados por casais interétnicos, em que a questão da transmissão da língua materna do cônjuge imigrante fica mais complexa, uma vez que a atitude em relação às línguas e culturas envolvidas pode não ser compartilhada pelo casal. Essa visão tem fundamento, pois "identidades linguísticas e culturais em jogo, como já afirmamos, exercem um papel importante na promoção, ou não, do bilinguismo familiar" (COELHO, 2009, p. 20).

Neste estudo, houve uma situação em que um entrevistado mencionou o estabelecimento de um acordo juntamente com seu cônjuge - porque um era descendente e falante de alemão e o outro de italiano - assim não iriam privilegiar uma ou outra língua. A decisão, nesse caso, foi a de não ensinar nenhuma das duas línguas aos filhos, permanecendo apenas a língua portuguesa.

Depreende-se que a opção de ensinar ou não aos filhos pode partir de uma intervenção consciente, planejada de uma política familiar. Nesse sentido, o fato de um dos cônjuges ser falante da língua dominante, por exemplo, da língua oficial do país onde reside, pode levar ao uso exclusivo ou predominante dessa língua no ambiente familiar e, por conseguinte, ao não estímulo do bilinguismo nesse 
contexto. A partir dessa situação, verifica-se que "A morte de uma língua não é necessariamente decorrente de uma operação violenta, se por violência entendemos o contato de alguma forma militar" (RASO; MELLO; ALTENHOFEN, 2011, p. 19). Nesses casos, a origem da língua se deve, muito mais, pelo fato de que outra língua se torna cada vez mais prestigiosa ou necessária nas atividades cotidianas, administrativas, econômicas e educacionais.

Dentre outros motivos citados, por parte dos pais que optaram em não ensinar a língua de imigração aos filhos, retoma-se a discussão anterior sobre o desprestígio que possuem alguns falares em detrimento de outros e a imagem que se tem do falante que fala desse jeito:

[...] eu já até escutei dos pais que eles não quiseram ensinar o alemão porque é o Hunsrückisch dialekt, Hunsrückisch, como falam né? E que é o alemão da roça, alemão feio, não sei o que, e daí eles preferiram não ensinar para as crianças. Tem a ver com esse clichê de alemão quadrado, é alemão colono e coisas assim, né, então muitos não fizeram questão de falar com os filhos. Por outro lado, já escutei crianças falando também 'eu queria ter aprendido alemão, mas meus pais não ensinaram, né? Eu não sei se é bem isso, porque hoje a maioria dos adultos hoje pensa que queria ter aprendido quando era criança, mas se realmente houve esse interesse quando criança, daí eu acho que não. (Trecho entrevista Tese MARTINY, 2015, p. 267, grifos nossos).

Conforme o entrevistado, ainda fica muito presente a desvalorização de falar o dialeto, porque seria uma maneira de falar desprestigiada, ligada à noção de um falante 'atrasado' socialmente, culturalmente. Em muitas falas, foram encontrados, recorrentemente, alguns substantivos e adjetivos: vergonha, errado, medo, feio, colono, preconceito, atrasado, bloqueio. São termos que evidenciam o estigma já citado que carregam muitos falantes de língua alemã na região, pois são associados a uma condição social menos favorecida economicamente ou à situação de ausência de estudo dos primeiros imigrantes e seus descendentes que tinham, geralmente, apenas o ensino primário.

Sobre o assunto, Busse e Sella (2012) reafirmam que a interferência de uma língua em outra, como acontece no caso do alemão no português, na região estudada, é um fenômeno visto de forma negativa, principalmente 
v. 7 (2)

297-313

ago/dez 2017

com relação aos mais jovens, "o que pode estar relacionado a avaliações pautadas em aspectos sociais, orientadas, principalmente, pelo nível de escolaridade" (BUSSE; SELLA, 2012, p. 89).

Nas falas dos docentes de língua alemã que foram entrevistados, aparece mais uma vez o motivo de que os pais deixam de ensinar a língua alemã aos filhos porque são falantes de diferentes dialetos alemães e alegam que não gostariam que seus filhos aprendessem o alemão 'errado', para que os filhos não sofram preconceito ou tenham dificuldades no aprendizado.

Há um discurso recorrente nas entrevistas de que, ao ensinar ao filho a língua de imigração, o falante iria ter dificuldades em aprender o português no início do processo escolar. Essa postura retoma uma antiga concepção de que uma língua poderia interferir negativamente na aprendizagem de outra, no entanto, várias pesquisas apontam que não há fundamento linguístico para tanto.

Depreende-se que o que existe é o estigma que muitos relatam no momento em que apresentam alguma variação fonética, então, acabam deixando de falar outra língua que não seja a majoritária. Um dos entrevistados faz esta observação:

[...] a partir do momento que eu comecei a ir para a aula esse bloqueio se tornou maior. Então, eu lembro que minha mãe falava, por exemplo, números em alemão, porque os números são complicados e eu falava 'não' fala em português. Então eu, dava assim, uma certa raiva, por que você está falando em alemão? Fala em português! Mas ela continuava falando, tanto que até hoje ela fala (Trecho entrevista Tese MARTINY, 2015, p. 268).

Na fala do entrevistado, verifica-se um mal-estar causado pelo falante, quando chega ao meio escolar e se depara com o desprestígio social devido ao seu falar, o que acaba ocasionando um distanciamento da língua alemã, aprendida no contexto lar, e a vontade de falar apenas a língua prestigiada socialmente.

Assim como Rajagopalan (2013), defende-se a necessidade de intervir em assuntos relativos à linguagem, como está sendo refletido sobre as línguas de imigração: 
[...] mesmo nesses casos, há motivos de sobra para atuação no campo da política linguística, posto que milhões e milhões de pessoas são discriminadas e humilhadas por terem o sotaque que as elites consideram de baixo prestígio, inculto, bárbaros e assim por diante" (RAJAGOPALAN, 2013, p. 42).

Semelhante situação foi verificada na fala de mais entrevistados, havendo, inclusive, um que mencionou a questão do falante que possui o alemão como língua materna ou que é bilíngue alemão/português, quando chega à escola, e tem esse momento considerado como o marco inicial para o silenciamento da língua do lar.

Eu acho que assim que eles começam a ir à escola e só se fala português com as outras crianças daí eles acham muito difícil, é muito mais fácil para eles falar o português, até as próprias alunas que eu tenho, por exemplo, as vezes eu falo em alemão, elas respondem em português e eu acabo falando em português, porque é mais fácil, então eu também não quero ser diferente (Trecho entrevista Tese MARTINY, 2015, p. 269, grifos nossos).

Nesta fala, observa-se a dificuldade do entrevistado de falar a língua alemã mesmo em situação de sala de aula, devido à maior facilidade de se falar a língua portuguesa, justamente porque essa última acaba sendo a língua mais usada cotidianamente na escola e o alemão fica em segundo plano. A situação, como aparece no relato, faz com que o próprio docente fale a língua majoritária para se adequar à interlocução, uma vez que não quer se sentir "diferente", ou seja, quer se sentir parte do grupo, dialogar.

Também fica clara, na citação, a necessidade de falar o alemão por se tratar de uma língua com uma estrutura própria que necessita de prática. Além disso, pode-se retomar a questão do bloqueio, que pode impedir muitas interações em sala de aula. O medo de errar ou de falar o dialeto influenciam negativamente no aprendizado, por isso um trabalho de valorização e desmitificação se faz necessário.

Na fala da mesma docente, fica esclarecido o viés da necessidade de adequação ao falar.

Eu aprendi o dialeto em casa, só falava alemão esse dialeto que chamam de Hunsrückisch até entrar na escola com sete anos 
v. 7 (2) 297-313 ago/dez 2017

daí eu aprendi a falar o português e depois eu vim pro Paraná, parei de estudar e voltei a estudar de novo com vinte anos. (...) Estudei em Ivoti lá tinham cinco horas aula por semana de alemão eu saí razoavelmente bem de lá e eu tinha uma noção de Hochdeutsch. (...) Tinha um primo que dava risada de mim porque a esposa e o pastor quando iam lá em casa e eu queria falar diferente, eu queria falar mais pro Hochdeutsch como ela, né? Adequava à situação. Como eu sempre fiz, mesmo depois quando me tornei professora que tinha terminado todos os estudos eu quando encontro parentes ainda falo o dialeto com eles (Trecho entrevista Tese MARTINY, 2015, p. 269).

Pelo excerto, pontua-se o conhecimento do falante do dialeto e do padrão que podem ser usados em momentos distintos de interação, a depender de com quem se está falando, ou seja, adequando-se à circunstância comunicativa, aos interlocutores.

Essa é uma prática que poderia ser incentivada com relação aos alunos e demais conhecedores de dialetos e não, simplesmente, ignorálos ou substituí-los por não serem considerados o padrão da língua. Uma conscientização que precisa ser trabalhada, para não haver esse preconceito, como ficou retratado também no relato anterior, momento em que um parente 'tirou sarro'.

O que se percebe é que, quando não há uma consciência linguística, as vantagens do falar bilíngue são deixadas de lado e o falante passa a não falar mais a língua aprendida em casa em detrimento da língua majoritária. Os benefícios que o bilinguismo poderia trazer são esquecidos, não se abordam as questões relativas ao profissional ou acadêmico, ou mesmo como herança cultural.

Alguns entrevistados mencionaram vivências pessoais, ligadas a dificuldades que passaram devido à língua de imigração, durante também o período ditatorial:

Em casa com os meus pais até os oito, nove anos só falava alemão, depois quando fui para a escola. Eu lembro assim que eu tinha minhas dificuldades que eu peguei o finalzinho da Ditadura, era 1979, e aí colocaram uma professora que não falava um "a" em alemão para dar aula para a turma do $1^{0}$ ano, ali eu senti assim que a comunicação não existia, mas compreensão rapidamente acaba fluindo, você entra e um 
coleguinha já sabe um pouco mais daí e quando vê você já está falando também e vai embora. Não senti assim que isso me travasse de algum sentido só aquele confronto mesmo (Trecho entrevista Tese MARTINY, 2015, p. 272, grifo nosso).

A partir da fala do entrevistado, observa-se que a proibição do falar também contribuiu para a não continuidade da preservação de línguas de imigração, em muitos casos. Esse é um fato que sempre é relembrado pelos imigrantes e seus descendentes com muito pesar, pois foram situações de desconforto, como apareceu no relato e ficou nítido também nas expressões corporais dos entrevistados, quando mencionavam a falta de liberdade em usar a sua língua materna.

Pereira e Costa (2011) também fazem menção ao vocábulo "confronto", que aparece em cenários de bilinguismo em que convivem línguas e culturas diferentes e, por conseguinte, as línguas em contato e, consequentemente, em conflito. Segundo os autores,

Por esta razão, as atitudes dos falantes em relação ao idioma ou à variedade linguística podem se apresentar ora como algo positivo, ora como algo negativo, o que pode levar os sujeitos a uma atitude de inquietação, de insegurança, cuja consequência pode ser de amar e odiar uma das línguas de seu reportório em uma atitude abertamente antagônica (PEREIRA; COSTA, 2011, p. 49).

É essa relação paradoxal que se percebeu em muitos relatos, momento em que os entrevistados falavam sobre seu contato com o idioma pelas suas vivências familiares ou devido ao período mencionado da Ditadura, que contribuiu também para o afastamento da língua de imigração.

O confronto, por causa do uso da língua alemã, se repetiu na fala de outros entrevistados. No caso de um deles, os pais eram alemães e vieram fugidos da Guerra para casarem no Rio de Janeiro, em 1914, e, depois, foram morar no Rio Grande do Sul. De maneira que os pais não ensinaram os filhos a falarem alemão, pois haviam sofrido muito na Guerra e, na sequência, no Brasil, também tiveram que se adaptar para aprender o português e não mais falaram em alemão.

Ainda sobre o assunto, Pereira e Costa (2011) citam que, quando a língua materna foi abandonada, por pressões em torno da promoção da língua nacional brasileira, havia a esperança de que a língua de imigração poderia um dia ser retomada, posteriormente, em condições políticas menos adversas, sendo, assim, um abandono temporário. No entanto, 
v. 7 (2)

297-313 ago/dez 2017

em muitos casos, não se retomou a língua mais tarde. Além disso, os autores mencionam o distanciamento que foi ocorrendo com relação àquela língua materna vinda com os imigrantes que, atualmente, deve estar extinta no continente europeu, devido a forças de outras variantes tidas como língua oficial. Assim,

Certamente a língua que hoje se busca aprender é a língua oficial do moderno país formado após a emigração, não mais aquela que existira. [...]. Por essa razão, a língua que hoje se busca aprender é a variante considerada padrão, ou seja, com tradução literária, não a língua de seus antepassados restrita à modalidade oral [...] (PEREIRA; COSTA, 2011, p. 58).

A partir dessa constatação, os autores retomam um depoimento citado por Moser: "Somos italiano (sic), mas não sabemos falar italiano, só sabemos o dialeto... que não é língua" (MOSER apud PEREIRA; COSTA, 2011, p. 58). Semelhante fala foi aludida neste estudo, mas em torno dos descendentes de imigrantes alemães. Essa posição enfatiza, como mencionam os referidos estudiosos, a eficiência do processo de desvalorização de um povo que se inicia com a desvalorização da sua língua.

Outro entrevistado, que optou por não ensinar aos filhos a língua de imigração, cita que o motivo era a dificuldade de encontrar tempo, uma vez que o ensino de uma língua, segundo considera, demanda muita dedicação.

Nas palavras do entrevistado, a não transmissão foi

Por causa do dia a dia, o dia a dia é muito corrido, tem tantas outras ocupações, né? Até porque se opta por uma, uma, linguagem mais fácil pelo dia a dia, né? Uma linguagem tradicional. Olha, na verdade, existe a falta de você sentar com o seu filho e praticar com veemência com profundidade, pra você ensinar a língua alemã você precisa tempo, não é fácil, não é fácil aprender a língua alemã (Trecho entrevista Tese MARTINY, 2015, p. 267).

Esta fala retoma a questão da língua alemã ser vista, recorrentemente, como difícil, complexa e, por isso, precisaria de tempo disponível para ensinar-aprender, como sendo algo à parte de suas interações na família, optando-se, assim, pelo mais 'fácil' e prático.

Constatou-se que praticamente todos os entrevistados desta pesquisa acreditam no desaparecimento do uso linguístico do alemão no 
município. Afirmam isso devido à diminuição das interações na língua e à falta de políticas locais voltadas ao ensino (formal e informal), bem como na ausência de outras atividades culturais mais autênticas e não apenas discursos em festas típicas.

Além disso, nas falas dos entrevistados, há muitas colocações sobre a importância da língua e da cultura alemã para a comunidade, mas, ao mesmo tempo, não há iniciativas para promovê-las, nem da comunidade, nem do poder público, nem dos próprios falantes que passam a não mais falar e/ou ensinar a língua alemã devido aos motivos relatados ao longo deste texto.

\section{Considerações finais}

Por todas as reflexões feitas ao longo deste artigo, é que se verifica a necessidade latente de agir no Brasil, a fim de acompanhar as ações de promoção do resgate e manutenção do plurilinguismo, envolvendo o poder público e outras instâncias da sociedade.

No caso do município pesquisado, a falta de políticas linguísticas e educacionais locais, bem como essa ausência de conscientização linguística, tende a culminar, fatalmente, no desaparecimento da língua de imigração, pois apenas discursos pautados na colonização e de outras práticas culturais não possuem respaldo diante da não vivência, da não experiência com a interação linguística efetiva na comunidade.

Dessa maneira, reitera-se a colocação de Calvet (2000), ao afirmar que a continuação das línguas, que estão sempre em transformação depende das práticas dos falantes e não apenas de decisões em torno de planejamentos linguísticos isolados.

Concorda-se, enfim, com Altenhofen (2013), que discute que, para a preservação da língua de imigração, há a necessidade de trabalho efetivo de conscientização linguística (language awareness) por meio de projetos que, entre outras medidas, assessoram pais na decisão de que línguas ensinar aos filhos, sendo instruídos sobre os benefícios do bilinguismo, bem como criando uma imagem positiva a respeito da língua minoritária. Assim, mais do que defender uma língua ameaçada de extinção, a ideia é incentivar a promoção da diversidade de línguas e a conscientização sobre o papel da pluralidade linguística e, com isso, levar os indivíduos para uma ação, movendo os pais à educação bilíngue de seus filhos. 
v. $7(2)$ 297-313 ago/dez 2017

Seria possível, a partir disso, fortalecer as línguas dos grupos teuto-brasileiros por meio de uma educação plurilíngue, na qual as variantes do português e os vários dialetos da língua alemã fossem tratados com respeito na constituição social, histórica e identitária dos falantes.

Acredita-se, portanto, que, para que haja uma mudança cultural e linguística com relação à língua de imigração na localidade estudada, é necessário que o bilinguismo seja aceito e valorizado na comunidade, descontruindo estereótipos, pois as línguas em contato/conflito compreendem uma complexa intersecção psicológica, linguística e social e as atitudes dos falantes interferem diretamente para a continuidade de um falar ou não.

\section{Referências}

ALTENHOFEN, C. V. Bases para uma política linguística das línguas minoritárias no Brasil. In: NICOLAIDES, C. et al (Orgs.). Política e Políticas Linguísticas. Campinas: Pontes Editores, 2013, p. 93-116.

BUSSE, S.; SELLA, A. F. Uma análise das crenças e atitudes linguísticas dos falantes do Oeste do Paraná. SIGNUM: Estudos Linguísticos, Londrina, n. 15, v. 1, p. 77-93, jun. 2012. Disponível em: <www.uel.br/revistas/uel/index.php/ signum/article/download/.../11179>. Acesso em 10 de dez. de 2014.

CALVET, Louis-Jean. El porvenir de las lenguas. Revista El Correo - Guerra y paz em el frente de las lenguas. Francia, 2000. Disponível em <http://maintenance. unesco.org/404/?host=www. unesco.org\&uri=/courier/2000_04/sp//dosso. $\mathrm{html} />$. Acesso em $15 \mathrm{dez}$. de 2014.

Sociolinguística: uma introdução crítica. Tradução de Marcos Marcionilo. São Paulo: Parábola, 2002.

As políticas lingüísticas. Tradução de Isabel de Oliveira Duarte, Jonas Tenfen e Marcos Bagno. São Paulo: Parábola, 2007.

CAMACHO, R. G. Da linguística formal à linguística social. São Paulo: Parábola, 2013.

CEZÁRIO, M. M.; VOTRE, S. Sociolinguística. In: MARTELOTTA, Mário Eduardo (org.). Manual de linguística. 2. reimpr. São Paulo: Contexto, 2009, p. 141155 .

COELHO, V. M. de G. Casais Interétnicos - Filhos Bilíngues? Representações como Indícios de Políticas de (não) Transmissão da Língua Minoritária da Família. 2009.129 f. Dissertação (Metrado em Linguística Aplicada) - Programa de Pós-Graduação em Linguística Aplicada, Instituto de Estudos da Linguagem da Universidade Estadual de Campinas, Campinas - SP, 2009. Disponível em <http://www.bibliotecadigital.unicamp.br/document/?code=000467487>. Acesso em: 20 jan. de 2014. 
FRITZEN, M. P. "Ich spreche anders, aber das ist auch deutsch": línguas em conflito em uma escola rural localizada em zona de imigração no sul do Brasil. Trab. Ling. Aplic., Campinas, v. 47, n.2, p. 341-356, Jul./Dez. 2008.

LAMBERT, W. W.; LAMBERT, W. E. Psicologia social. Trad. Álvaro Cabral. Rio de Janeiro: Zahar, 1966.

MARTINY, F. M. Políticas linguísticas e educacionais: o ensino de língua alemã em Marechal Cândido Rondon, Paraná. 2015. 317 f. Tese (Doutorado em Letras) - Universidade Estadual do Oeste do Paraná, Cascavel, 2015.

MORENO FERNANDEZ, F. Principios del sociolingüística y sociologia del linguaje. Barcelona: Ariel, 1998.

PEREIRA, M. C.; COSTA, R. V. da. Política Linguística: o caso dos cenários bi(multi)língues. In: VON BORSTEL, Clarice N.; COSTA-HÜBES, Terezinha da C. (Orgs.). Linguagem, cultura e ensino. Cascavel: EDUNIOESTE, 2011, p. 4966.

RAJAGOPALAN, K. Política linguística: do que trata afinal? In: NICOLAIDES, Cristine et al (Orgs.). Política e Políticas Linguísticas. Campinas SP: Pontes Editores, 2013, p. 19-42.

RASO, T.; MELLO, H.; ALTENHOFEN, C.; Os contatos linguísticos e o Brasil. In: MELLO, H.; ALTENHOFEN, C.; RASO, T. (Orgs.). Os contatos linguísticos no Brasil. Belo Horizonte: Editora UFMG, 2011, p. 13-56.

SAATKAMP, V. Desafios, lutas e conquistas: história de Marechal Cândido Rondon. Cascavel: Assoeste, 1985.

SCHNEIDER, M. N. Atitudes e concepções linguísticas e sua relação com as práticas sociais de professores em comunidades bilíngües alemão-português do Rio Grande do Sul. 2007, 286 f. Tese (Doutorado em Linguística Aplicada) - Instituto de Letras, Universidade Federal do Rio Grande do Sul. Porto Alegre - RS, 2007. Disponível em: <http://www.lume.ufrgs.br/handle/10183/13098>. Acesso em: 16 jan. 2012.

TARGANSKI, S. Rumo ao novo Eldorado. Marechal Cândido Rondon: Editora Germânica, 2007.

VON BORSTEL, C. N. Aspectos do bilingüismo: alemão e português em Marechal Cândido Rondon, Paraná, Brasil. 1992. 297 f. Dissertação (Mestrado em Letras/Linguística) - Universidade Federal de Santa Catarina, Florianópolis - SC, 1992.

Contato lingüístico e variação em duas comunidades bilíngües do Paraná. Rio de Janeiro, 1999. 202 f. Tese (Doutorado em Linguística) - Curso de Pós-Graduação em Letras Universidade Federal do Rio de Janeiro, Rio de Janeiro - RJ, 1999.

A linguagem sociocultural do Brasildeutsch. Pedro e João Editores: São Carlos, 2011. 